\title{
Expression of Cannabinoid CB1 Receptors by Vagal Afferent Neurons Is Inhibited by Cholecystokinin
}

\author{
Galina Burdyga, ${ }^{1}$ Simon Lal, ${ }^{1}$ Andrea Varro, ${ }^{1}$ Rod Dimaline, ${ }^{1}$ David G. Thompson, ${ }^{2}$ and Graham J. Dockray ${ }^{1}$ \\ ${ }^{1}$ Physiological Laboratory, University of Liverpool, Liverpool L69 3BX, United Kingdom, and 2Division of Gastroenterology, Hope Hospital, University of \\ Manchester, Manchester M6 8HD, United Kingdom
}

\begin{abstract}
Both inhibitory (satiety) and stimulatory (orexigenic) factors from the gastrointestinal tract regulate food intake. In the case of the satiety hormone cholecystokinin (CCK), these effects are mediated via vagal afferent neurons. We now report that vagal afferent neurons expressing the CCK-1 receptor also express cannabinoid CB1 receptors. Retrograde tracing established that these neurons project to the stomach and duodenum. The expression of CB1 receptors determined by RT-PCR, immunohistochemistry and in situ hybridization in rat nodose ganglia was increased by withdrawal of food for $\geq 12 \mathrm{hr}$. After refeeding of fasted rats there was a rapid loss of CB1 receptor expression identified by immunohistochemistry and in situ hybridization. These effects were blocked by administration of the CCK-1 receptor antagonist lorglumide and mimicked by administration of CCK to fasted rats. Because CCK is a satiety factor that acts via the vagus nerve and $\mathrm{CB} 1$ agonists stimulate food intake, the data suggest a new mechanism modulating the effect on food intake of satiety signals from the gastrointestinal tract.
\end{abstract}

Key words: afferent; appetite; cannabinoids; CCK; cholecystokinin; satiety; vagus

\section{Introduction}

Signaling to the CNS from the gastrointestinal tract involves multiple pathways and mediators. Gut hormones released during either feeding or fasting can modulate food intake, e.g., inhibition of feeding by cholecystokinin (CCK) (Gibbs et al., 1973) and PYY3-36 (Batterham et al., 2003) and stimulation by ghrelin (Kojima et al., 1999). These effects are thought to be mediated both by direct effects of circulating hormones on the hypothalamus and by actions on vagal afferent neurons that project to the nucleus tractus solitarius (NTS). In addition, vagal afferent neurons may respond directly to mechanical, chemical, or inflammatory stimuli, whereas spinal afferent neurons serving the gastrointestinal tract are involved primarily in transmission of noxious stimuli (Andrews, 1986; Janig and Morrison, 1986; Holzer, 1998).

The brain-gut peptide CCK is released from enteroendocrine cells by fat and protein and in turn acts at CCK-1 receptors on vagal afferent neurons (Smith et al., 1981; Ritter and Ladenheim, 1985; Moran et al., 1990; Moriarty et al., 1997; McLaughlin et al., 1999; Broberger et al., 2001; Reidelberger et al., 2003). The latter may include populations of neurons acting as gastric mechanoreceptors (Raybould et al., 1988; Schwartz et al., 1993) and as duodenal chemoreceptors (Eastwood et al., 1998). Recent work

Received Dec. 8, 2003; revised Jan. 22, 2004; accepted Jan. 23, 2004

We thank the Biotechnology and Bioscience Research Council and the Medical Research Council for financial support. We are also grateful to Stephen Attwood and Shakeel Saeed for help in obtaining human tissues.

Correspondence should be addressed to Graham Dockray, Physiological Laboratory, University of Liverpool, Crown Street, Liverpool L69 3BX, UK. E-mail: g.j.dockray@liv.ac.uk.

DOI:10.1523/JNEUROSCI.5404-03.2004

Copyright $\odot 2004$ Society for Neuroscience $\quad$ 0270-6474/04/242708-08\$15.00/0 suggests that several other neurohumoral factors may modulate the effects of CCK on vagal afferent nerve discharge. Thus receptors (Ob-R) for the long (functional) form of the satiety hormone leptin are expressed by the same vagal neurons that express CCK-1 receptors (Buyse et al., 2001; Burdyga et al., 2002; Peiser et al., 2002), and there are synergistic interactions between CCK and leptin for both inhibition of food intake (Barrachina et al., 1997) and afferent nerve discharge (Wang et al., 1997) Conversely, the same population of neurons also expresses receptors for the orexigenic peptide orexin-A (OX-R1), which inhibits the stimulatory effect of CCK on vagal afferent nerve discharge (Burdyga et al., 2003).

It has been known for many years that cannabinoids are associated with stimulation of appetite (Mechoulam and Hanu, 2001). Both central and peripheral sites of action may be involved. In the present context it is notable that recent work indicates that the effect of endogenous cannabinoids on appetite is mediated by vagal afferent neurons, suggesting a role in modulating gut-brain signaling (Gomez et al., 2002). Two types of cannabinoid receptor have been characterized, CB1 and CB2. The latter appears to be expressed mainly by immune cells, whereas CB1 is expressed by many central and peripheral neurons, possibly including vagal afferent neurons (Pertwee, 1997; Freund et al., 2003; Partosoedarso et al., 2003). In the present study we examined the identity and expression of $\mathrm{CB} 1$ receptors in vagal afferent neurons. We now report that $\mathrm{CB} 1$ receptors are expressed by neurons that also express CCK-1 receptors, and importantly the expression of these receptors is increased with fasting (when plasma CCK concentrations are low) and rapidly decreased by feeding (and by CCK). The data suggest a new action of CCK in inhibiting food intake. 
Table 1. Sequences of primers used in RT-PCR

\begin{tabular}{|c|c|c|c|}
\hline Primer names & Sequence $5^{\prime}-3^{\prime}$ & $\begin{array}{l}\text { Product } \\
\text { size (bp) }\end{array}$ & $\begin{array}{l}\text { GenBank } \\
\text { accession number }\end{array}$ \\
\hline \multicolumn{4}{|l|}{ Rat } \\
\hline CB1-sense & CATCATCATCCACACGTCAG & 330 & U40395 \\
\hline CB1-antisense & ATGCTGTTGTCTAGAGGCTG & & \\
\hline CB2-sense & CGGCTTGGAGTTCAACCCTA & 481 & AF176350 \\
\hline CB2-antisense & ACAACAAGTCCACCCCATGAG & 533 & AF041244 \\
\hline OX-R1-sense & TGATGAGCGCTGGGCAGATGAACT & & \\
\hline OX-R1-antisense & GACCAGGCAGGCAGCAGAATG & & \\
\hline $\mathrm{CCK}_{\mathrm{A}}$-sense & GTCCCGCGTCTGGCAAACAAAGT & 245 & NM_012688 \\
\hline $\mathrm{CCK}_{A}^{A}$-antisense & CGTAGGCCACCACCATCACAATCC & & \\
\hline GAPDH-sense & GACCCCTTCATTGACCTCAACT & 732 & X02231 \\
\hline GAPDH-antisense & CTCAGTGTAGCCCAGGATGCC & & \\
\hline \multicolumn{4}{|l|}{ Human } \\
\hline CB1-sense & CAAGCCCGCATGGACATTAGGTTA & 291 & U73304 \\
\hline CB 1-antisense & TCCGAGTCCCCCATGCTGTTATC & & \\
\hline CB2-sense & TCCCACTGATCCCCAATGACTACC & 459 & X74328 \\
\hline CB2-antisense & AGGATCTCGGGGCTTCTTCTTTTG & & \\
\hline
\end{tabular}

${ }^{a}$ The sequences of the various primers used in RT-PCR are given together with the size of the predicted product.

\section{Materials and Methods}

Tissues. Studies were made using adult male Wistar rats (250-450 gm; Biomedical Services Unit, University of Liverpool) that were housed at $22^{\circ} \mathrm{C}$ under a $12 \mathrm{hr}$ light/dark cycle with ad libitum access to food and water (unless stated otherwise). Samples of human vagal nerve trunks were obtained during resections for gastro-esophageal carcinoma and cleanly dissected from the serosa; in addition, nodose ganglia were obtained at resections for head and neck tumors (Burdyga et al., 2003). Human tissues were separated rapidly and either immersed in RNA later (Ambion, Austin, TX) or fixed in 4\% paraformaldehyde for morphological studies. The work was approved by the Multi-Centre and Local Ethics Committee of Salford and Trafford Health Authority, and written consent was obtained from all patients.

Fasting-refeeding. Rats were fasted for up to $48 \mathrm{hr}$ (water ad libitium) and subsequently refed for up to $5 \mathrm{hr}$. Some fasted animals received CCK8 (Bachem, St Helens, Merseyside, UK) (10 nmol, i.p.) or saline and were killed after $2.5 \mathrm{hr}$. In addition, some rats that were fasted for $48 \mathrm{hr}$ received the CCK-1 receptor antagonist lorglumide ( $10 \mathrm{mg} / \mathrm{kg}$, i.p.) 15 min before refeeding and were killed $2 \mathrm{hr}$ after refeeding. Either whole nodose ganglia or in some cases the separated mid, caudal, and rostral regions were dissected; in a few experiments gastric corpus was taken for comparison. For RT-PCR, ganglia were pooled from several animals. Alternatively, ganglia were fixed for immunohistochemistry or in situ hybridization. For experimental studies involving fasting and refeeding, ganglia from at least six rats in each group were examined.

$R T-P C R$. Total RNA was extracted from pooled $(8-14)$ rat nodose ganglia and from three human vagal trunks in Trizol Reagent (Invitrogen, Paisley, UK). Samples were treated with DNase, reverse transcribed, and processed for PCR using BIO-X-ACT DNA Polymerase (Bioline) using the primers listed in Table 1 as described previously (Burdyga et al., 2002, 2003). PCR products were cloned directly into the pGEM-T Easy cloning vector (Promega, Madison, WI), and sequence analysis was performed using an automated dideoxy method.

Retrograde tracing and axonal transport. Rats were anesthetized with Diazepam $(2.5 \mathrm{mg} / \mathrm{kg}$, i.m.) and Hypnorm $(0.3 \mathrm{ml} / \mathrm{kg}$, i.m.), and True Blue ( $5 \% \mathrm{w} / \mathrm{v})$ was aseptically administered at four sites ( $3 \mu \mathrm{l} \mathrm{each)} \mathrm{in} \mathrm{the}$ stomach or duodenum; the area was then washed extensively and the wound closed. Animals were given prophylactic antibiotic (Baytril, 0.2 $\mathrm{ml} / \mathrm{kg}$, i.m.). After $2 \mathrm{~d}$, rats were fasted for $24 \mathrm{hr}$, anesthetized deeply with sodium pentabarbitone $(60 \mathrm{mg} / \mathrm{ml}$, i.p.), and fixed by transcardial perfusion with paraformaldehyde $(4 \% \mathrm{w} / \mathrm{v})$. True Blue staining was visualized in nodose ganglia before dual-labeling immunohistochemistry, and images were processed using the Axio Vision 3.0 Imaging system (Carl Zeiss Vision, Oberkochen, Germany).

For studies of vagal transport of receptors, rats were fasted for $24 \mathrm{hr}$ and then anesthetized with Diazepam (2.5 mg/kg, i.m.) and Hypnorm $(0.3 \mathrm{ml} /$ $\mathrm{kg}$, i.m.). A crushing ligature was placed on the cervical vagus on one side; after $4 \mathrm{hr}$ animals were killed with an overdose of sodium pentobarbitone, and both vagi were sectioned for immunohistochemistry.

Immunohistochemistry. Rats either were killed by $\mathrm{CO}_{2}$ inhalation and the ganglia were immersed in fixative or were deeply anesthetized with sodium pentabarbitone $(60 \mathrm{mg} / \mathrm{ml}$, i.p.) and transcardially perfused with $4 \%$ paraformaldehyde solution in $0.1 \mathrm{PBS}, \mathrm{pH}$ 7.4. Ganglia were processed for immunohistochemistry as described previously (Burdyga et al., 2002, 2003). Either affinity-purified goat or rabbit polyclonal antibodies to CB1 were used (Santa Cruz Biotechnology, Santa Cruz, CA). The CCK-1 receptor was localized using an affinity-purified rabbit polyclonal antibody raised against the $\mathrm{N}$-terminal region of the rat CCK-1 receptor (kind gift of the late John Walsh, CURE/Gastroenteric Biology Centre, University of California Los Angeles). Phosphorylation of cAMP response element-binding protein (CREB) was detected by affinitypurified rabbit polyclonal phospho-CREB (Ser133) antibody (New England BioLabs, Beverly, MA). Affinity-purified goat polyclonal antibodies to rat-mouse and human leptin receptor (Ob-R) were obtained from Research Diagnostic (Flanders, NJ) and Linco Research (St. Charles, $\mathrm{MO})$. Affinity-purified rabbit polyclonal antibody to cocaine and amphetamine-regulated transcript (CART) and affinity-purified rabbit polyclonal antibody to OX-R1 were obtained from Alpha Diagnostic International (San Antonio, TX). Secondary antibodies were used as appropriate and included donkey anti-goat IgG and donkey anti-rabbit IgG conjugated to fluorescein isothiocyanate or Texas Red (Jackson ImmunoResearch, West Grove, PA). Specificity of immunostaining was determined by preincubation with an excess of appropriate peptide and omitting of primary antibody. Sections were examined using an Axioplan Universal microscope, and images were processed using the Axio Vision 3.0 Imaging system (Carl Zeiss Vision).

In situ hybridization. Cryostat sections $(10 \mu \mathrm{m})$ of quickly frozen $\left(-80^{\circ} \mathrm{C}\right)$ nodose ganglia were thaw mounted on UV-treated poly-Llysine-coated slides, fixed in $4 \%$ paraformaldehyde in $1 \times$ PBS, and acetylated in $0.25 \mathrm{M}$ acetic anhydride/ 0.1 triethanolamide $(10 \mathrm{~min})$. Sections were dehydrated in $70-95 \%$ ethanol and stored in $95 \%$ ethanol at $4^{\circ} \mathrm{C}$ or dried at $-70^{\circ} \mathrm{C}$ until required. Oligonucleotide probes complementary to bases 4-51,349-396, and 952-999 of the rat CB1 receptor or 192-239, 922-969, and 969-1016 of rat CCK-1 receptor (Sigma-Genosys) were 3 'end labeled with $\left[{ }^{35} \mathrm{~S}\right] \mathrm{dATP}(10 \mathrm{mCi} / \mathrm{ml}$; Amersham Biosciences, Buckinghamshire, UK), purified using QIAquick nucleotide removal kit (Qiagen, Crawley, UK), and used at a concentration of $3000 \mathrm{cpm} / \mu \mathrm{l}$ in hybridization buffer [50\% formamide, $10 \%$ dextran sulfate, $4 \times$ SSPE $\left(1 \times \mathrm{SSPE}\right.$ is composed of $3 \mathrm{M} \mathrm{NaCl}, 0.2 \mathrm{M} \mathrm{NaH}_{2} \mathrm{PO}_{4} \cdot 2 \mathrm{H}_{2} \mathrm{O}$, and $0.2 \mathrm{M}$ EDTA, pH 7.4), $0.2 \mathrm{mg} / \mathrm{ml}$ sheared salmon sperm DNA, $0.1 \mathrm{mg} / \mathrm{ml}$ polyA RNA, $5 \times$ Denhardt's, and $20 \mathrm{~mm}$ DTT]. Hybridization with mixtures of the three CB1 or three CCK-1 oligonucleotides (1:1:1, in both cases) was performed overnight at $42^{\circ} \mathrm{C}$; sections were washed in $1 \times$ SSC $(150 \mathrm{~mm}$ $\mathrm{NaCI}, 15 \mathrm{~mm}$ sodium citrate, $\mathrm{pH} 7.0)$ at $55^{\circ} \mathrm{C}(30 \mathrm{~min}), 22^{\circ} \mathrm{C}(30 \mathrm{~min})$, $0.1 \times$ SSC $(30 \mathrm{sec})$, and dehydrated through ethanol, air dried, dipped in autoradiographic emulsion (LM-1, Amersham Biosciences), and exposed for 4-6 weeks before development. Sections were developed, counterstained with hematoxylin and eosin, dehydrated, and mounted using Histomount (Oncogene Research, Boston, MA). Silver grains were visualized using an Axioplan Universal microscope, and images were processed using AxioVision 3.0 Imaging system (Carl Zeiss) combined with dark-field and bright-field illumination. Control slides were hybridized with 100-fold excess of unlabeled oligonucleotides.

\section{Results}

\section{Identification of $\mathrm{CB} 1$ expression in rat nodose neurons}

In initial studies we used RT-PCR to identify cannabinoid receptor transcripts in rat nodose ganglia. Using material from fasted rats (see below), we found a band of the predicted size corresponding to CB1 (Fig. 1A). The product was cloned, and sequencing established complete identity with that predicted for CB1 (data not shown). By comparison, a product consistent with expression of the $\mathrm{CB} 2$ receptor in rat nodose ganglion was barely detectable (Fig. $1 B$ ). There were, however, clear bands corre- 


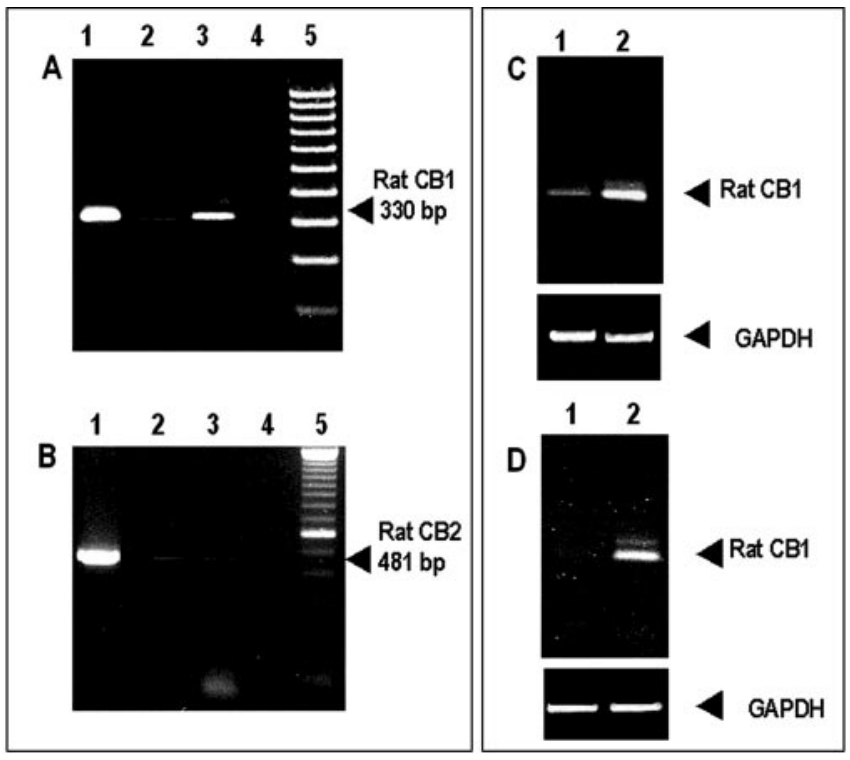

Figure 1. RT-PCR indicates $C B 1$ expression in rat nodose ganglia. $A, R T-P C R$ of rat gastric corpus (lane 1), nodose ganglion from fed (lane 2) and fasted (lane 3) rats (pool of 10 ganglia in each case), and template-free control (lane 4) using primers yielding a predicted product of 330 bp from rat CB1 (100 bp size ladder; lane 5). Note the presence of strong bands in lanes 1 and 3. $B$, Similar data for $C B 2$ using primers yielding a predicted product of $481 \mathrm{bp}$. C, The abundance of CB1 in extracts of whole nodose ganglion from fasted rats (lane 2) is higher than in fed rats (lane 1) (samples pooled from 6 animals in each case), whereas RT-PCR products corresponding to GAPDH are similar. D, When extracts (pooled from 8 rats) were prepared from the mid and caudal regions of the nodose ganglion of fed rats (lane 1), CB1 (but not GAPDH) was undetectable, whereas there was a strong signal in fasted rats (lane 2).

sponding to both $\mathrm{CB} 1$ and $\mathrm{CB} 2$ in the corpus region of the rat stomach (Fig. 1A,B). To determine whether $\mathrm{CB} 1$ receptor expression might be regulated by feeding, we compared extracts from rats fed ad libitum and fasted for $48 \mathrm{hr}$. Interestingly, there was markedly depressed abundance of the CB1 RT-PCR product in rats fed ad libitum (Fig. $1 \mathrm{~A}$ ). This was most apparent in extracts of the mid and caudal regions of the ganglion but was also apparent in samples of the entire ganglion (Fig. 1C,D).

\section{Immunohistochemical localization of CB1}

We then used immunohistochemistry to determine the cellular origin of CB1 in nodose ganglia. Positively stained neuronal cell soma were found throughout the nodose ganglia of fasted rats, and consistent with the data described above, the signal was stronger in the mid and caudal regions of the ganglia from fasted rats (Fig. $2 A, B$ ). Colocalization studies indicated that in these regions $82 \pm 3 \%$ of stained neurons expressed both $\mathrm{CB} 1$ and CCK-1 receptors, whereas $6 \pm 2 \%$ expressed CB1 alone and $12 \pm$ 2\% CCK-1 alone (Fig. 2C-E). The CCK-1 receptor is not well expressed in rostral regions of the ganglion, and here there were few examples of colocalization. A common population of nodose ganglion neurons is already known to express CCK-1, Ob-R, OX$\mathrm{R} 1$, and CART immunoreactivity (Broberger et al., 1999; Burdyga et al., 2003), and consistent with this we also found CB1 to be colocalized with Ob-R, OX-R1, and CART (data not shown). Neurons in the mid and caudal regions of the rat nodose ganglion project to the gastrointestinal tract (Green and Dockray, 1988), and to determine whether this population of neurons corresponded to those expressing $\mathrm{CB} 1$, we studied the distribution after retrograde labeling of cells by injection of True Blue into the stomach and duodenum. In both cases, a similar proportion of True Blue-labeled cells exhibited coexpression of CB1 and
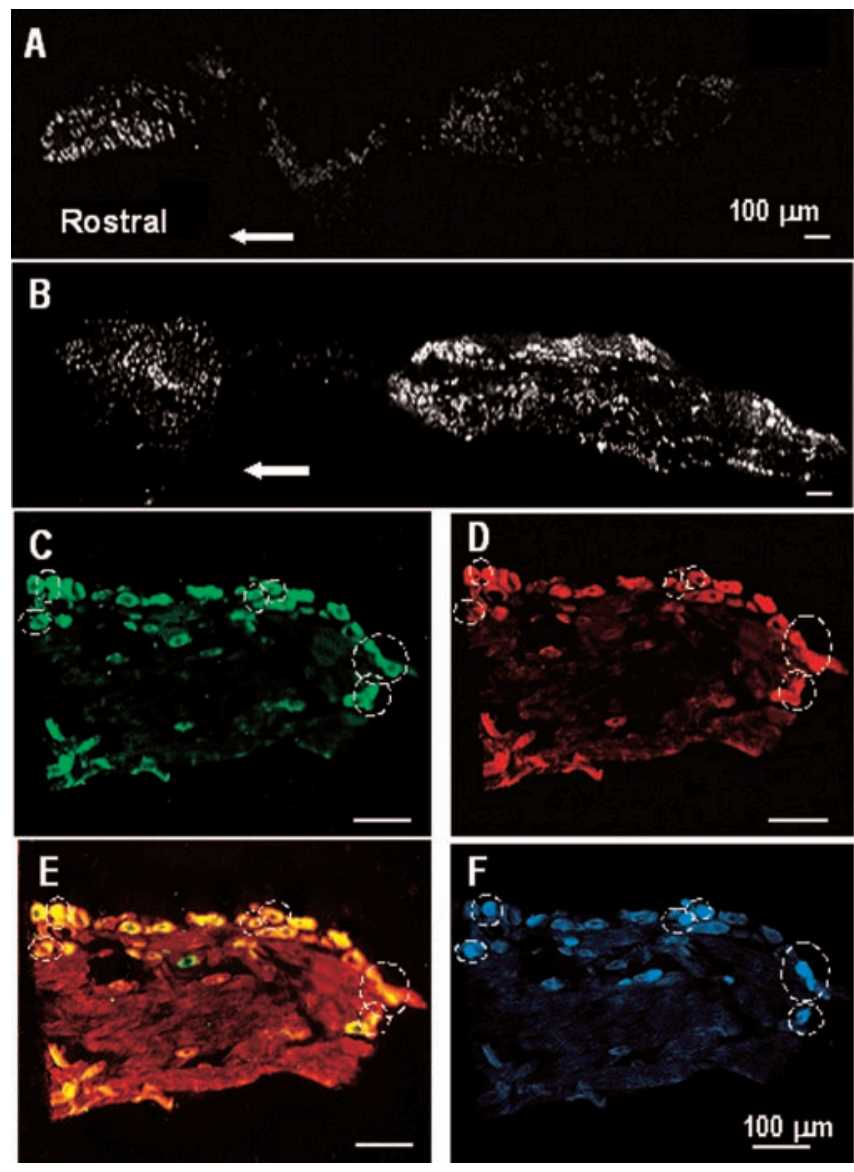

Figure 2. Localization of CB1 immunoreactivity in rat nodose ganglion. $A$, In rats fed ad libitum there is a population of $C B 1$ immunoreactive neuronal cell soma in the rostral part of the ganglion (indicated by direction of arrow), but little immunoreactivity in more caudal parts of the ganglion. $B$, In rats fasted for $48 \mathrm{hr}$, CB1-positive neurons in the rostral population are again revealed, together with immunoreactive cell soma in the mid and caudal regions of the ganglion. $C$, CB1-immunoreactive neuronal cell soma in the mid region of the rat nodose ganglion. $D$, The same section costained for CCK-1 immunoreactivity; $E$, the overlay of (and D.F, True Blue fluorescence in the same section after administration of the tracer into the gastric corpus. Circled neurons contain True Blue and express both CB1 and CCK-1 receptors. Scale bars, $100 \mu \mathrm{m}$.

CCK-1 receptors (stomach 58\%, duodenum $47 \%$ of all True Blue-labeled cells) (Fig. 2C-F); $<10 \%$ of True Blue-labeled cells expressed only CB1 or CCK-1 receptors. Because CCK-1 receptors in vagal afferent neurons are transported toward the periphery (Moran et al., 1990; Moriarty et al., 1997), we asked whether the same was the case for CB1 receptors. Ligation of the cervical vagal nerve trunk was associated with an accumulation of CB1 receptors on the central side, consistent with peripheral translocation (Fig. 3).

\section{Expression in human vagus}

To establish that the observations in rat nodose ganglia also applied to humans, we then showed by RT-PCR that a band of the appropriate size occurred in both human vagal nerve trunk and gastric corpus (Fig. 4A); in contrast CB2 was expressed in stomach but not vagus (Fig. $4 B$ ). Moreover, immunohistochemical studies confirmed the presence of CB1 immunoreactivity in a population of neuronal cell soma (Fig. $4 C, D$ ) corresponding to the large neurons shown previously to express CCK-1, Ob-R, and OX-R1 receptors (Burdyga et al., 2003). 


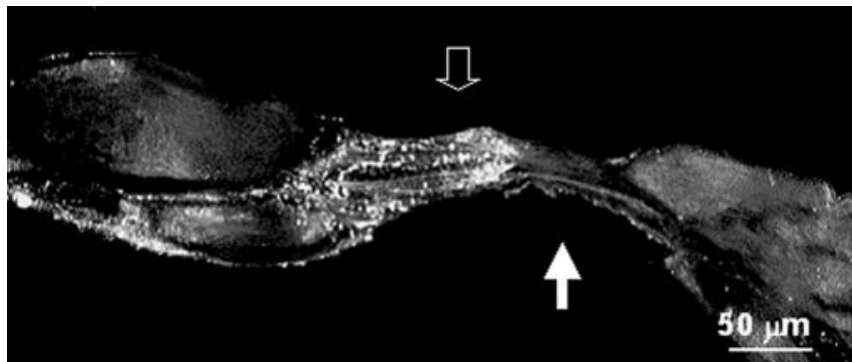

Figure 3. Nerve trunk ligation reveals that $C B 1$ receptors are transported toward the periphery in rat vagus nerve. Accumulated CB1 immunoreactivity (open arrow) on the rostral side of a crushing ligature (filled arrow). Scale bar, $50 \mu \mathrm{m}$.
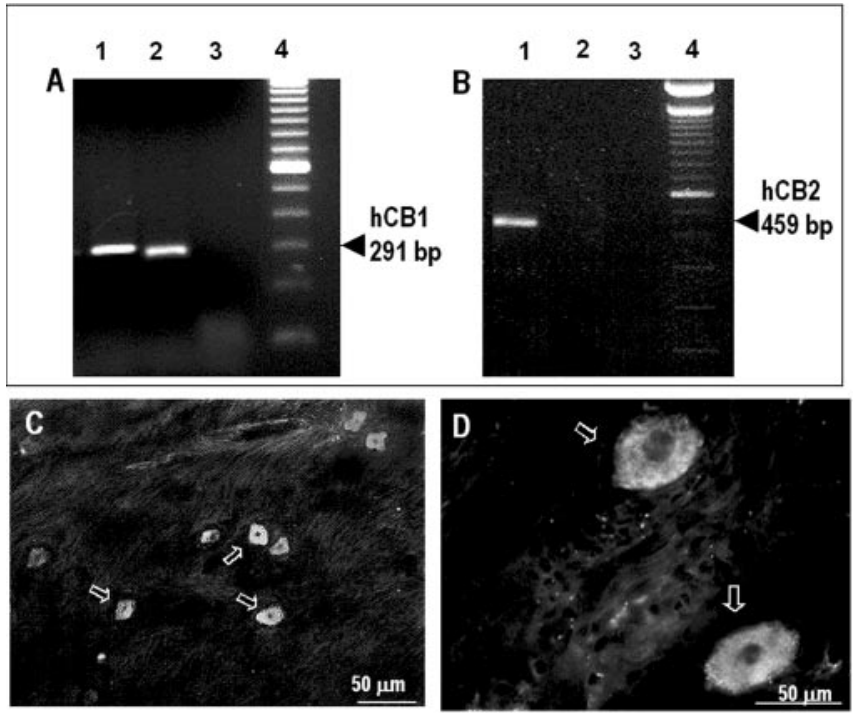

Figure 4. Identification of $C B 1$ expression in human vagus. $A, R T-P C R$ of human vagus nerve (lane 1) and gastric corpus (lane 2) showing bands corresponding to the predicted size of the human (B1 product (291 bp) (lane 3, template-free control; lane 4, 100 bp ladder). B, Similar data for CB2; the predicted human product of $459 \mathrm{bp}$ is found in gastric corpus (lane 2) but not vagus (lane 1). C, D, CB1-immunopositive neurons in neuronal cell soma of human nodose ganglion at low and higher power, respectively. Scale bars, $50 \mu \mathrm{m}$.

\section{Regulation by fasting}

In view of the RT-PCR data suggesting upregulation of CB1 expression in vagal afferent neurons of fasted rats, we compared the expression with that of CCK-1 and OX-R1 in nodose ganglia of rats fasted for $48 \mathrm{hr}$ or fed ad libitum. Although the expression of $\mathrm{CB} 1$ receptors was increased with fasting, there was no apparent difference in the abundance of CCK-1 or OX-R1, or glyceraldehyde-3-phosphate dehydrogenase (GAPDH) (Fig. 5). Thus although CB1 and CCK-1 receptors are expressed by the same neurons, the apparent increased expression of $\mathrm{CB} 1$ in fasted rats appears not to be caused by a nonspecific change in expression of all receptors. The increased expression of CB1 could be detected within $8 \mathrm{hr}$ of withdrawing food and appeared maximal after $12 \mathrm{hr}$ (data not shown).

We then applied in situ hybridization to characterize feedingdependent changes in CB1 expression. In rats fed ad libitum, it was not possible to identify CB1-expressing cells in the mid and caudal regions of the ganglia, whereas CCK-1 expressing neurons were identified readily (Fig. 6A,B). In sharp contrast, after removing food for $12-48 \mathrm{hr}$, both CB1 and CCK-1 receptors were found in these regions of the ganglion (Fig. 6C,D). An excess of the appropriate unlabeled oligonucleotides inhibited the in

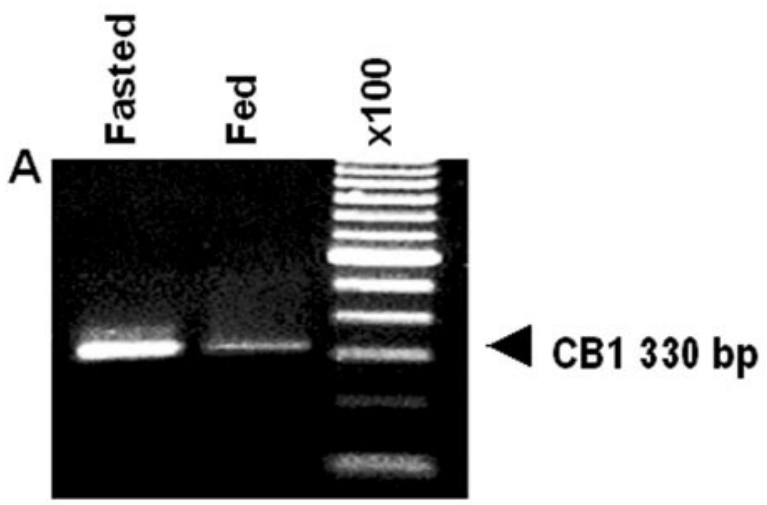

B
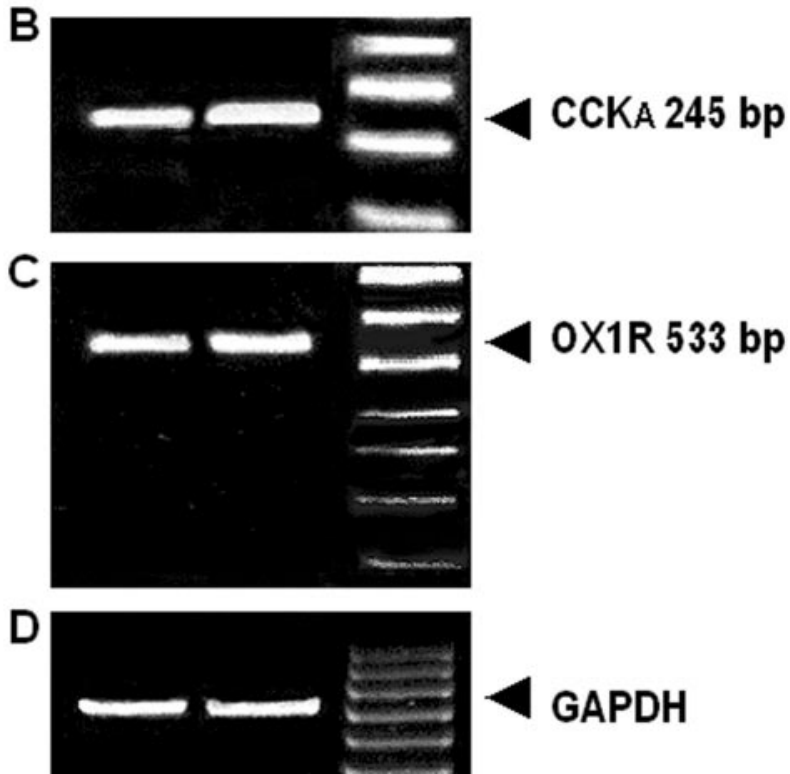

Figure 5. RT-PCR identification of $C B 1, C C K-1$, and $0 X-R 1$ expression in nodose ganglia from fed and fasted rats. A, By RT-PCR, CB1 product is present in higher abundance in extracts of the whole nodose ganglion of fasted rats compared with rats fed ad libitum (for details, see Fig. 1). $B-D$, In contrast, in the same extracts there is similar abundance of bands corresponding to RT-PCR products of CCK-1 and 0X-R1 receptors, and GAPDH.

situ hybridization signal with both $\mathrm{CB} 1$ and $\mathrm{CCK}-1$ receptors (Fig. 6G, J).

\section{Role of CCK in inhibiting CB1 receptor expression}

The data presented above are consistent with the hypothesis that feeding downregulates CB1 expression in a subset of vagal afferent neurons projecting to the gut. To directly test this idea we then examined the effects of refeeding of fasted rats. Using in situ hybridization, we found depressed CB1 expression within $2 \mathrm{hr}$ of refeeding fasted rats, and by $5 \mathrm{hr}$, the signal was virtually abolished (Fig. $7 A, B$ ). In contrast, refeeding for $30 \mathrm{~min}$ had no effect on the localization of CB1 demonstrated by in situ hybridization (data not shown).

Because CB1 was expressed in neurons that also expressed CCK-1 receptors and because CCK is released by food, we then asked whether CCK might mediate the downregulation of CB1. As a first step we demonstrated that administration of CCK replicated the effect of food in downregulating CB1 expression in fasted rats. Within $2.5 \mathrm{hr}$ of administration of CCK8 $(10 \mathrm{nmol}$, i.p.), a substantial loss of $\mathrm{CB} 1$ transcripts was detected by in situ hybridization (Fig. $7 \mathrm{C}$ ). To provide evidence that this population of neurons responded to exogenous CCK, we used phosphoryla- 
tion of the transcription factor CREB, which is known to occur with a rise in intracellular calcium (Shaywitz and Greenberg, 1999; Lonze and Ginty, 2002). Administration of CCK8 (10 nmol, i.p.) increased nuclear phospho-CREB staining in nodose neurons that also expressed CB1 and CCK-1 receptors, consistent with the capacity of these neurons to respond to CCK (Fig. 7D-M).

To determine whether endogenous CCK influenced CB1 expression, we then administered the CCK-1 receptor antagonist lorglumide to rats fasted for $48 \mathrm{hr}$ and refed for $2 \mathrm{hr}$. Importantly, administration of lorglumide prevented the loss of $\mathrm{CB} 1$ receptor detected by immunohistochemistry that occurred with refeeding, implicating endogenous CCK in this response (Fig. 8A-D). Moreover, lorglumide preserved up to $2 \mathrm{hr}$ after refeeding the CB1 transcripts detected by in situ hybridization (Fig. 8E-H).

\section{Discussion}

The action of CCK as a satiety signal has been known for 30 years (Gibbs et al., 1973). There is good evidence that this effect is mediated by vagal afferent neurons (Smith et al., 1981; Ritter and Ladenheim, 1985). Recent evidence suggests that the same neurons also express $\mathrm{Ob}-\mathrm{R}$ and OX-R1 (Buyse et al., 2001; Burdyga et al., 2002, 2003; Peiser et al., 2002), and the putative peptide transmitter CART (Broberger et al., 1999). Previous studies have found little evidence to indicate dietary modulation of the expression of the relevant genes (Broberger et al., 1999, 2001). The main finding of the present study is that this neuronal population expresses the $\mathrm{CB} 1$ receptor, and importantly expression is increased by fasting and downregulated by CCK. The data provide a new insight into the action of CCK on vagal afferent neurons. The findings are interesting in view of the action of endogenous cannabinoids as stimulants of appetite because they suggest that the satiety effects of CCK may be mediated at least in part by decreased expression of CB1 receptors.

There have been various previous studies of the effects of food intake on expression of signaling molecules in vagal afferent neurons. A reduced-calorie diet or a fat-rich diet seemed to have little effect on CCK-1 and CCK-2 receptor expression in rat nodose ganglion or on the putative peptide satiety transmitter CART (Broberger et al., 1999). The finding that CB1 receptor expression was enhanced in the nodose ganglion of food-restricted rats was made using RT-PCR, in situ hybridization, and immunocytochemistry. The effect is apparently specific in that we did not find changes in the expression of CCK-1 and OX-R1 expression in the same neuronal population; however, CB1-expressing neurons in the rostral part of the nodose ganglion, which probably serve thoracic structures, appeared not to be sensitive to food restriction. It is known that $\mathrm{CB} 1$ receptors are found on the terminals of airway nerve fibers (Calignano et al., 2000), and it is probable that the $\mathrm{CB} 1$-expressing population neurons that we found in rostral rat nodose ganglion are linked to these effects and are function- ally distinct from the control of food intake. We also found CB1 expression in human nodose ganglia obtained at surgery. Whether there is food-regulated expression in the human ganglion will require further study. It is worth noting, however, that patients are normally fasted before surgery, so the expression is consistent with the data in the rat.

The endogenous cannabinoid system involves two putative receptors (CB1 and $\mathrm{CB} 2$ ) and several possible endogenous ligands, including anandamide and diarachidonoylglycerol. In the central and peripheral nervous systems, $\mathrm{CB} 1$ receptors are relatively widely distributed and often associated with retrograde inhibition of neuronal activity (Freund et al., 2003). Interestingly, in the cortex, CB1 receptors occur on GABAergic interneurons that also contain CCK. Possible interactions between CCK and CB1 expression in the CNS are still unexplored. In the context of visceral sensory transmission, the accumulated evidence points to effects of cannabinoids on both appetite and emesis (Van Sickle et al., 2001, 2003; Gomez et al., 2002; Partosoedarso et al., 2003). Recently, an increase in the abundance of anandamide has been shown in the intestine of rats deprived of food for $24 \mathrm{hr}$, and the appetite-stimulating effects of cannabinoids were shown to be mediated by the vagus nerve, suggesting a mechanism for gastrointestinal activation of appetite during fasting (Gomez et al., 2002). The present results now extend these observations by showing that the peripheral action of endogenous cannabinoids in stimulating appetite may be mediated by CCK-regulated expression of CB1 receptors. 

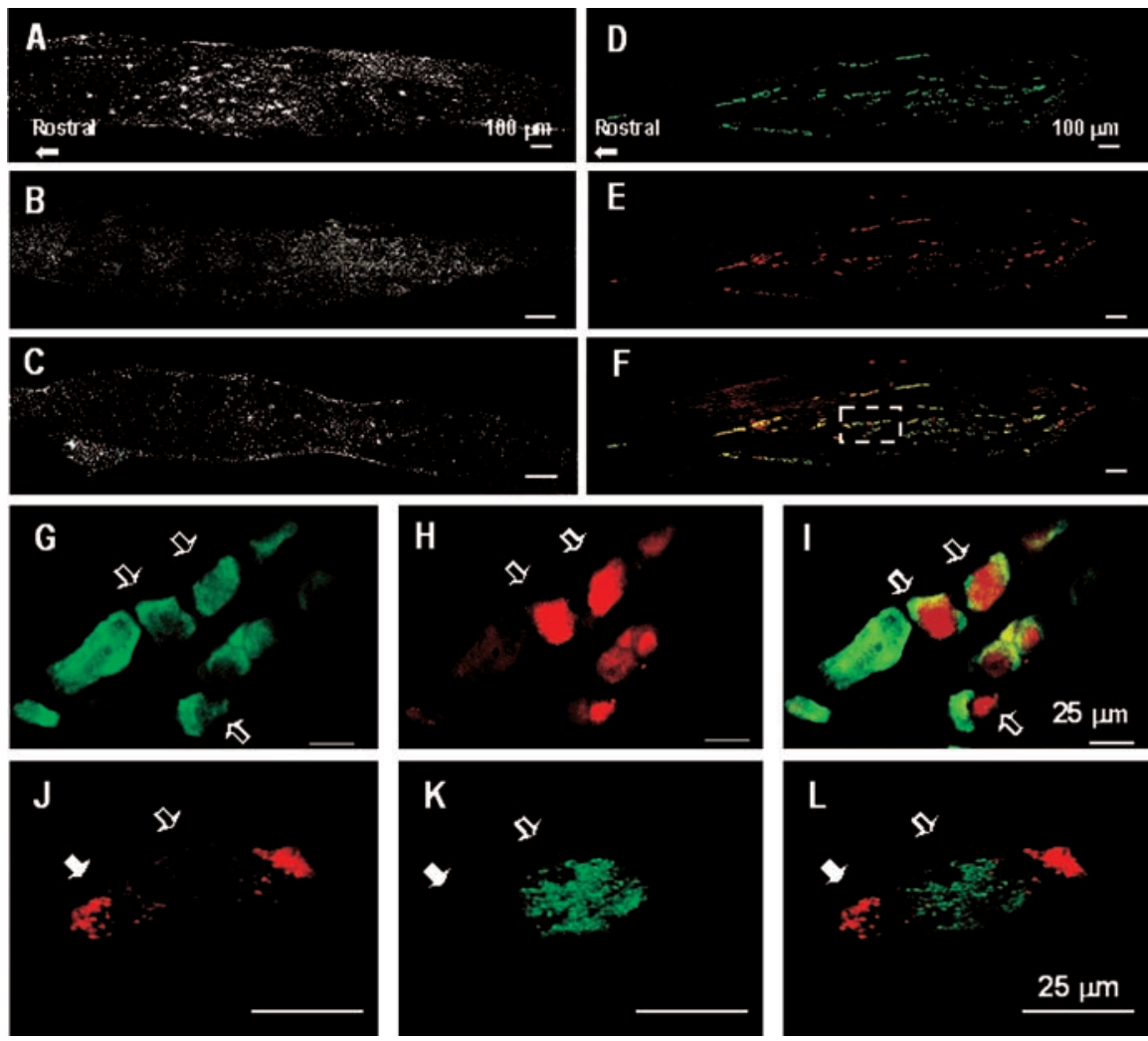

Figure 7. Refeeding and CCK8 downregulate CB1 expression in rat nodose ganglion. $A$, In situ hybridization of CB1 in rat nodose ganglion after fasting for $48 \mathrm{hr}$ (dark-field images; rostral direction indicated by arrow; see also Fig. 6). B, In a fasted rat, refed for $2.5 \mathrm{hr}$, there is virtually complete loss of CB1 transcripts revealed by in situ hybridization. C, Similarly, there is loss of the CB1 signal revealed by in situ hybridization in nodose ganglion after $48 \mathrm{hr}$ fasting and administration of CCK8 (10 nmol, i.p., $2.5 \mathrm{hr}$ before killing). $D$, Administration of CCK is associated with phosphorylation of (REB in neurons that express CB1 ( $E$ ). $F$, 0 verlay of $D$ and E. G, Higher-power magnification (region indicated by box in $F$ ) shows that (B1-expressing neurons (green) respond to administration of CCK8 indicated by colocalization (open arrows) of nuclear phospho-CREB ( $H$, red; l, overlay). J, Deconvolution microscopy of a single neuron showing CB1 immunoreactivity in cytosolic vesicles (filled arrows, red); $K$, nuclear phospho-CREB (open arrows, green); L, overlay. Scale bars: $A-F, 100 \mu \mathrm{m} ; G-L, 25 \mu \mathrm{m}$.

The localization of CB1 transcripts in nodose ganglion neurons detected by in situ hybridization was substantially reduced within $2 \mathrm{hr}$ of refeeding. Rapid inhibition of transcription or enhanced degradation of transcripts, or both, presumably accounts for this effect. Interestingly, there was also loss of CB1 protein detected by immunohistochemistry over a period of $2-5$ hr after refeeding of fasted rats. Nerve trunk ligation experiments indicated transport of $\mathrm{CB} 1$ receptors to the periphery, so presumably the loss of CB1 receptors from cell soma in the nodose ganglion is attributable to transport of newly synthesized receptor toward nerve terminals. Inevitably, it is likely to be many hours before the changes observed in CB1 expression in the nodose ganglion influence receptor abundance in the terminal regions. The central terminals of vagal afferents are closer to the cell body than gastrointestinal terminals, so any functional consequences of feeding-induced downregulation of CB1 might be anticipated to occur earlier at the central terminals.

The endogenous cannabinoid ligand anandamide is also an agonist for the vanilloid TRPV1 receptor (Zygmunt et al., 1999; Ross, 2003). It is well established that the satiety effects of CCK are mediated by neurons sensitive to the TRPV1 agonist capsaicin (Ritter and Ladenheim, 1985; Mercer et al., 1992). The affinity of anandamide for TRPV1 is lower than for CB1 receptors. It is conceivable, however, that increased anandamide production in the gut during food restriction (Gomez et al., 2002) leads to en- hanced vagal afferent neuron discharge via TRPV1 receptors and thereby generation of inappropriate satiety signals. The increased expression of CB1 receptors by these neurons in food restriction would therefore provide a mechanism to attenuate any activation of TRPV1 by intestinal anandamide.

Previous work has established that the vagal afferent population shown here to expresses CCK-1 and CB1 receptors also expresses the OX-R1 receptor and the functional (long) form of the leptin receptor, Ob-R (Burdyga et al., 2002, 2003). Orexin-A inhibits the action of CCK8 on vagal afferent discharge (Burdyga et al., 2003), and plasma concentrations of orexin increase with fasting (Komaki et al., 2001). It is worth noting that there is reported to be a synergy between OX-R1 and CB1 receptors (Hilairet et al., 2003). The fasting-induced CB1 receptor expression in vagal afferent neurons may therefore augment signaling via OX-R1 to enhance appetite by providing a counterbalance to visceral satiety signals. Thus, in addition to potentiating interactions between satiety factors acting on vagal afferents, e.g., CCK and leptin (Barrachina et al., 1997; Wang et al., 1997), the emerging evidence now supports the concept of synergistic interactions between orexigenic factors acting on the same pathway as well. There is also evidence for dietary modulation of CCKvagal signaling; for example, the satiety effects of CCK can be attenuated by feeding high fat or high protein diets (Covasa et al., 2001), although in this case the precise cellular mechanisms remain uncertain.

The neurochemical mechanisms regulating food intake have attracted considerable attention in recent years (Schwartz et al., 2000). It is now clear that at the level of the hypothalamus there are distinct neuronal systems associated with inhibition of food intake mediated, for example, by products of the proopiomelanocortin gene and CART and stimulation of food intake mediated, for example, by neuropeptide Y, orexin, agoutirelated peptide, melanocortin-concentrating hormone $(\mathrm{MCH})$, and $\mathrm{CB} 1$ receptors. The latter are colocalized with CART, the orexin precursor, $\mathrm{MCH}$, and corticotrophin-releasing hormone; moreover, in $\mathrm{CB}^{-/-}$mice the decreased body weight and decreased hypothalamic CART mRNA are compatible with central effects to regulate food intake (Cota et al., 2003). Hypothalamic circuits regulating food intake can be influenced by circulating satiety factors, e.g., leptin from adipose tissue and PYY from the gastrointestinal tract, as well as orexigenic factors, e.g., ghrelin from gastric endocrine (X-) cells (Kojima et al., 1999; Schwartz et al., 2000; Broberger and Hokfelt, 2001; Batterham et al., 2003). Although some gastrointestinal factors regulating food intake may act directly on the hypothalamus, it has been clear for some time that they may also act via vagal afferent nerve fibers terminating in the NTS and relaying on brain stem neurons projecting to the arcuate nucleus (Smith et al., 1981; Date et al., 2002; Luckman and Lawrence, 2003). CCK is probably the best studied ex- 
ample of a peptide acting through this system. The present data therefore add to evidence suggesting multiple interactions at the level of vagal afferent neurons to modulate satiety signaling.

In conclusion, the finding that the expression of $\mathrm{CB} 1$ receptors in vagal afferent neurons is decreased by food intake suggests a new dimension to the integrative role of the vagus nerve in mediating gutbrain signaling. In particular, it seems that CCK, which is recognized to act as a gutderived satiety signal, may decrease CB1 receptor expression in vagal afferent neurons and so influence the capacity of endogenous cannabinoids to enhance appetite by this route. It is worth noting that CB1 receptors have relatively high constitutive activity (Bouaboula et al., 1997), so that even in the absence of endogenous cannabinoid ligands, changes in CB1 expression may modulate vagal nerve function. Together the data suggest that vagal afferent neurons exhibit a hitherto unsuspected capacity for modulating gastrointestinal satiety signaling, which may in turn provide novel targets for therapeutic modulation of food intake.
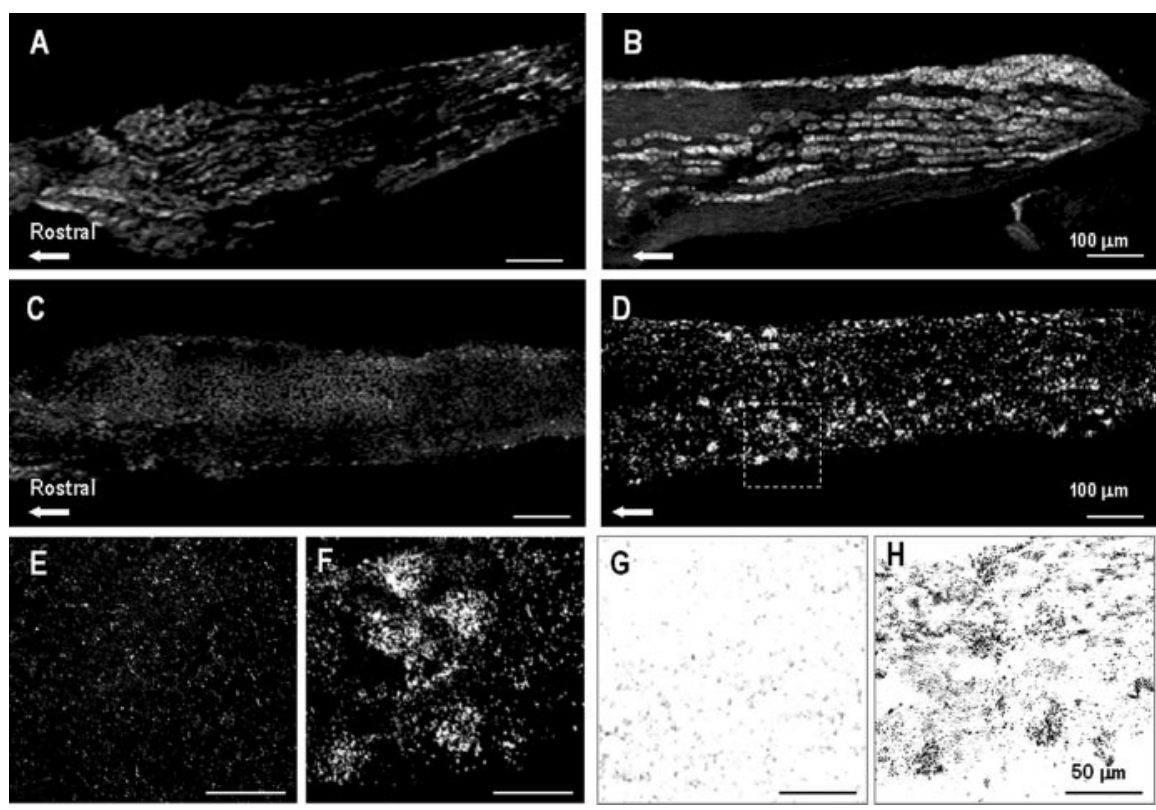

Figure 8. CCK mediates the effect of food in downregulating vagal CB1 expression. $A$, Immunocytochemical localization of CB1 in nodose ganglia after refeeding for $2 \mathrm{hr}$ after fasting for $48 \mathrm{hr}$ and administration of vehicle $15 \mathrm{~min}$ before refeeding (rostral direction indicated by arrow). $B$, In comparison, administration of the (CK-1 antagonist lorglumide 15 min before a refeeding period of $2 \mathrm{hr}$ after fasting for $48 \mathrm{hr}$ rat preserves $(B 1$ immunoreactivity. C, D, In situ hybridization (dark-field images) shows absence of $C B$ transcripts in nodose ganglia after vehicle treatment 15 min before a $2 \mathrm{hr}$ refeeding period after $48 \mathrm{hr}$ fast (see also Fig. 7) (C), but administration of the CCK-1 antagonist lorglumide inhibits the loss of CB1 transcripts (D). E, F, Higher-power dark-field images of $C$ and $D$ (box), respectively; $G, H$, bright-field images of $E, F$. Scale bars: $A-D 100 \mu \mathrm{m} ; E-H, 50 \mu \mathrm{m}$.

\section{References}

Andrews PL (1986) Vagal afferent innervation of the gastrointestinal tract. Prog Brain Res 67:65-86.

Barrachina MD, Martinez V, Wang L, Wei JY, Tache Y (1997) Synergistic interaction between leptin and cholecystokinin to reduce short-term food intake in lean mice. Proc Natl Acad Sci USA 94:10455-10460.

Batterham RL, Cohen MA, Ellis SM, Le Roux CW, Withers DJ, Frost GS, Ghatei MA, Bloom SR (2003) Inhibition of food intake in obese subjects by peptide YY3-36. N Engl J Med 349:941-948.

Bouaboula M, Perrachon S, Milligan L, Canat X, Rinaldi-Carmona M, Portier M, Barth F, Calandra B, Pecceu F, Lupker J, Maffrand JP, Le Fur G, Casellas P (1997) A selective inverse agonist for central cannabinoidreceptor inhibits mitogen-activated protein kinase activation stimulated by insulin or insulin-like growth factor 1. Evidence for a new model of receptor/ligand interactions. J Biol Chem 272:22330-22339.

Broberger C, Hokfelt T (2001) Hypothalamic and vagal neuropeptide circuitries regulating food intake. Physiol Behav 74:669-682.

Broberger C, Holmberg K, Kuhar MJ, Hokfelt T (1999) Cocaine- and amphetamine-regulated transcript in the rat vagus nerve: a putative mediator of cholecystokinin-induced satiety. Proc Natl Acad Sci USA 96:13506-13511.

Broberger C, Holmberg K, Shi TJ, Dockray G, Hokfelt T (2001) Expression and regulation of cholecystokinin and cholecystokinin receptors in rat nodose and dorsal root ganglia. Brain Res 903:128-140.

Burdyga G, Spiller D, Morris R, Lal S, Thompson DG, Saeed S, Dimaline R, Varro A, Dockray GJ (2002) Expression of the leptin receptor in rat and human nodose ganglion neurones. Neuroscience 109:339-347.

Burdyga G, Lal S, Spiller D, Jiang W, Thompson D, Attwood S, Saeed S, Grundy D, Varro A, Dimaline R, Dockray GJ (2003) Localization of orexin-1 receptors to vagal afferent neurons in the rat and humans. Gastroenterology 124:129-139.

Buyse M, Ovesjo ML, Goiot H, Guilmeau S, Peranzi G, Moizo L, Walker F, Lewin MJ, Meister B, Bado A (2001) Expression and regulation of leptin receptor proteins in afferent and efferent neurons of the vagus nerve. Eur J Neurosci 14:64-72.

Calignano A, Katona I, Desarnaud F, Giuffrida A, La Rana G, Mackie K, Freund TF, Piomelli D (2000) Bidirectional control of airway responsiveness by endogenous cannabinoids. Nature 408:96-101.
Cota D, Marsicano G, Tschop M, Grubler Y, Flachskamm C, Schubert M, Auer D, Yassouridis A, Thone-Reineke C, Ortmann S, Tomassoni F, Cervino C, Nisoli E, Linthorst AC, Pasquali R, Lutz B, Stalla GK, Pagotto U (2003) The endogenous cannabinoid system affects energy balance via central orexigenic drive and peripheral lipogenesis. J Clin Invest 112:423-431.

Covasa M, Marcuson JK, Ritter RC (2001) Diminished satiation in rats exposed to elevated levels of endogenous or exogenous cholecystokinin. Am J Physiol Regul Integr Comp Physiol 280:R331-R337.

Date Y, Murakami N, Toshinai K, Matsukura S, Niijima A, Matsuo H, Kangawa K, Nakazato M (2002) The role of the gastric afferent vagal nerve in ghrelin-induced feeding and growth hormone secretion in rats. Gastroenterology 123:1120-1128.

Eastwood C, Maubach K, Kirkup AJ, Grundy D (1998) The role of endogenous cholecystokinin in the sensory transduction of luminal nutrient signals in the rat jejunum. Neurosci Lett 254:145-148.

Freund TF, Katona I, Piomelli D (2003) Role of endogenous cannabinoids in synaptic signaling. Physiol Rev 83:1017-1066.

Gibbs J, Young RC, Smith GP (1973) Cholecystokinin elicits satiety in rats with open gastric fistulas. Nature 245:323-325.

Gomez R, Navarro M, Ferrer B, Trigo JM, Bilbao A, Del Arco I, Cippitelli A, Nava F, Piomelli D, Rodriguez de Fonseca F (2002) A peripheral mechanism for CB1 cannabinoid receptor-dependent modulation of feeding. J Neurosci 22:9612-9617.

Green T, Dockray GJ (1988) Characterization of the peptidergic afferent innervation of the stomach in the rat, mouse and guinea-pig. Neuroscience 25:181-193.

Hilairet S, Bouaboula M, Carriere D, Le Fur G, Casellas P (2003) Hypersensitization of the Orexin 1 receptor by the CB1 receptor: evidence for cross-talk blocked by the specific CB1 antagonist, SR141716. J Biol Chem 278:23731-23737.

Holzer P (1998) Neural injury, repair, and adaptation in the GI tract. II. The elusive action of capsaicin on the vagus nerve. Am J Physiol 275:G8-13.

Janig W, Morrison JF (1986) Functional properties of spinal visceral afferents supplying abdominal and pelvic organs, with special emphasis on visceral nociception. Prog Brain Res 67:87-114.

Kojima M, Hosoda H, Date Y, Nakazato M, Matsuo H, Kangawa K (1999) 
Ghrelin is a growth-hormone-releasing acylated peptide from stomach. Nature 402:656-660.

Komaki G, Matsumoto Y, Nishikata H, Kawai K, Nozaki T, Takii M, Sogawa H, Kubo C (2001) Orexin-A and leptin change inversely in fasting nonobese subjects. Eur J Endocrinol 144:645-651.

Lonze BE, Ginty DD (2002) Function and regulation of CREB family transcription factors in the nervous system. Neuron 35:605-623.

Luckman SM, Lawrence CB (2003) Anorectic brainstem peptides: more pieces to the puzzle. Trends Endocrinol Metab 14:60-65.

McLaughlin J, Grazia LM, Jones MN, D’Amato M, Dockray GJ, Thompson DG (1999) Fatty acid chain length determines cholecystokinin secretion and effect on human gastric motility. Gastroenterology 116:46-53.

Mechoulam R, Hanu L (2001) The cannabinoids: an overview. Therapeutic implications in vomiting and nausea after cancer chemotherapy, in appetite promotion, in multiple sclerosis and in neuroprotection. Pain Res Manag 6:67-73.

Mercer JG, Farningham DA, Lawrence CB (1992) Effect of neonatal capsaicin treatment on cholecystokinin-(CCK8) satiety and axonal transport of CCK binding sites in the rat vagus nerve. Brain Res 569:311-316.

Moran TH, Norgren R, Crosby RJ, McHugh PR (1990) Central and peripheral vagal transport of cholecystokinin binding sites occurs in afferent fibers. Brain Res 526:95-102.

Moriarty P, Dimaline R, Thompson DG, Dockray GJ (1997) Characterization of cholecystokininA and cholecystokininB receptors expressed by vagal afferent neurons. Neuroscience 79:905-913.

Partosoedarso ER, Abrahams TP, Scullion RT, Moerschbaecher JM, Hornby PJ (2003) Cannabinoid1 receptor in the dorsal vagal complex modulates lower oesophageal sphincter relaxation in ferrets. J Physiol (Lond) 550:149-158.

Peiser C, Springer J, Groneberg DA, McGregor GP, Fischer A, Lang RE (2002) Leptin receptor expression in nodose ganglion cells projecting to the rat gastric fundus. Neurosci Lett 320:41-44.

Pertwee RG (1997) Pharmacology of cannabinoid CB1 and CB2 receptors. Pharmacol Ther 74:129-180.

Raybould HE, Gayton RJ, Dockray GJ (1988) Mechanisms of action of pe- ripherally administered cholecystokinin octapeptide on brain stem neurons in the rat. J Neurosci 8:3018-3024.

Reidelberger RD, Castellanos DA, Hulce M (2003) Effects of peripheral CCK receptor blockade on food intake in rats. Am J Physiol Regul Integr Comp Physiol 285:R429-R437.

Ritter RC, Ladenheim EE (1985) Capsaicin pretreatment attenuates suppression of food intake by cholecystokinin. Am J Physiol 248:R501-R504.

Ross RA (2003) Anandamide and vanilloid TRPV1 receptors. Br J Pharmacol 140:790-801.

Schwartz GJ, McHugh PR, Moran TH (1993) Gastric loads and cholecystokinin synergistically stimulate rat gastric vagal afferents. Am J Physiol 265:R872-R876.

Schwartz MW, Woods SC, Porte D Jr, Seeley RJ, Baskin DG (2000) Central nervous system control of food intake. Nature 404:661-671.

Shaywitz AJ, Greenberg ME (1999) CREB: a stimulus-induced transcription factor activated by a diverse array of extracellular signals. Annu Rev Biochem 68:821-861.

Smith GP, Jerome C, Cushin BJ, Eterno R, Simansky KJ (1981) Abdominal vagotomy blocks the satiety effect of cholecystokinin in the rat. Science 213:1036-1037.

Van Sickle MD, Oland LD, Ho W, Hillard CJ, Mackie K, Davison JS, Sharkey KA (2001) Cannabinoids inhibit emesis through CB1 receptors in the brainstem of the ferret. Gastroenterology 121:767-774.

Van Sickle MD, Oland LD, Mackie K, Davison JS, Sharkey KA (2003) Delta9-tetrahydrocannabinol selectively acts on CB1 receptors in specific regions of dorsal vagal complex to inhibit emesis in ferrets. Am J Physiol Gastrointest Liver Physiol 285:G566-G576.

Wang YH, Tache Y, Sheibel AB, Go VL, Wei JY (1997) Two types of leptinresponsive gastric vagal afferent terminals: an in vitro single-unit study in rats. Am J Physiol 273:R833-R837.

Zygmunt PM, Petersson J, Andersson DA, Chuang H, Sorgard M, Di Marzo V, Julius D, Hogestatt ED (1999) Vanilloid receptors on sensory nerves mediate the vasodilator action of anandamide. Nature 400:452-457. 